\section{Ameloblastic Fibrosarcoma: A Case Report and Literature Review}

\author{
João Paulo Silva Servato ${ }^{1}$, Paulo Rogério de Faria ${ }^{2}$, Cássio Vinhadelli Ribeiro ${ }^{1}$, \\ Sergio Vitorino Cardoso', Paulo Rogério de Faria ${ }^{1}$, Fernando Luiz Dias ${ }^{3}$, Ana \\ Lúcia Amaral Eisenberg ${ }^{4}$, Adriano Mota Loyola ${ }^{1}$
}

\author{
'Department of Oral and Maxillofacia \\ Pathology, UFU - Universidade Federal \\ de Uberlândia, Uberlândia, MG, Brazil \\ ${ }^{2}$ Department of Morphology, \\ UFU - Universidade Federal de \\ Uberlândia, Uberlândia, MG, Brazil \\ ${ }^{3}$ Division of Head and Neck Surgery, \\ INC - Instituto Nacional do Câncer, \\ Rio de Janeiro, RJ, Brazil \\ ${ }^{4}$ Division of Pathology, INC - \\ Instituto Nacional do Câncer, \\ Rio de Janeiro, RJ, Brazil \\ Correspondence: Adriano Mota \\ Loyola, Universidade Federal de \\ Uberlândia Av. Pará, 1720, Campus \\ Umuarama, 38400-902 Uberlândia, \\ MG, Brasil. Tel: +55-34-3218-2703. \\ e-mail: loyolaam@yahoo.com.br
}

Key Words: odontogenic tumor, malignant odontogenic tumor, ameloblastic fibrosarcoma, immunohistochemistry, diagnosis.

\section{Introduction}

Among the malignant odontogenic tumors (MOTs), ameloblastic fibrosarcoma (AFS) is the most common. It is defined as an odontogenic tumor composed of malignant ectomesenchyme in which variable quantities of a benign epithelial component can be seen. It is regarded as the malignant counterpart of ameloblastic fibroma (AF). However, most cases were diagnosed as primary malignant processes (1-5).

Heath et al. (6) first described AFS in 1887. Since then, there were about 100 cases of similar microarchitectural features described in the literature. The World Health Organization's (WHO's) classification of odontogenic tumors (OTs) designated AFS a distinctive neoplasm since the inaugural "Blue Book" edition, published in 1972 (7). The essence of this view has remained unaltered since that time $(1,8)$.

To diagnose AFS histologically, as proposed by the WHO (1), it is important the identification of columnar and/ or cuboidal benign ameloblastic epithelial cells arranged in budding and branching cords, admixed with islands and knots. All these components are included in a highly cellular malignant connective stromal component, with cells showing variable degrees of anaplasia (1). Although AFS was first described 120 years ago, information about its epidemiology, treatment, predictive factors and expected outcomes is very limited, and is based mainly on case reports (9-12).

Some MOTs showing inductive phenomena in an AFS background have been described. In those cases, when the inductive process resulted only in the deposition of dentine, the lesions were called ameloblastic fibrodentinosarcomas (AFDSs); when dentine and enamel were identified concurrently, the term ameloblastic fibro-odontosarcoma (AFOS) was used $(1,13)$. Discussions about the pathogenetic and clinicopathological relationships among AFS, AFDS, and AFOS were presented in the literature, but no consensus has been attained to date.

Moreover, there are few reports on the proliferative potential of AFS, based on cell cycle markers. There is also a lack of data on the effects of the sarcomatous component of the lesion on proliferative activity and differentiation aspects of the ameloblastic epithelium present in AFS. Taken together, these data could improve the understanding of tumor pathogenesis and progression and aid in the differentiation of subtle malignant transformations of AF.

The aim of this report was to describe a case of AFS with an immunohistochemical evaluation. There is also a discussion of the clinicopathological characteristics of AFS and the nosological relationships of AFS to AFDS and AFOS based on a systematic review of literature. 


\section{Case Report}

A 32-year-old non-white woman was referred for evaluation and treatment of a large and persistent malignant swelling in the left mandible. The patient complained of pain and dysphagia for 4 months. An extraoral examination disclosed a large, firm swelling, involving the left mandibular ramus. Examination of other head and neck structures and a general physical evaluation yielded unremarkable findings. An intraoral examination revealed lingual and buccal cortical bone expansion affecting the mandibular body, with no clinical or imaging evidence of cortical perforation. Oral mucosa and mandibular nerve functions were normal and intact. Plain radiographic examinations showed an ill-demarcated and partially corticated multilocular radiolucency affecting the left posterior mandible. An incisional biopsy was performed, followed by routine histopathology, resulting in the diagnosis of primary AFS. En bloc surgical resection from the second premolar to the anterior ramus region was performed under general anesthesia. The resected specimen measured $8 \times 6 \mathrm{~cm}$, and showed clear margins, clinically and histologically. Immediate reconstruction was performed using an autogenous right iliac bone graft, stabilized with a titanium plate. The patient did not undergo any other treatment. Histopathological examination of the resected specimen showed evidence of scant cords and nests of odontogenic epithelium scattered within the mesenchymal stromal tissue (Fig. 1). Stromal components contained hyperchromatic and pleomorphic cells, as well as numerous mitotic structures (Fig. 1A-C). There were foci of necrosis near the epithelial islands. Odontogenic epithelial islands, in a follicular or trabecular aspect, showed hyperplasia of peripheral columnar cells; these cells showed hyperchromatic and discrete anisokaryosis (Fig. 1A-C). In some places, dentinoid material of variable dimensions was associated closely with the epithelial islands.

Immunohistochemistry was performed on 3- $\mu$ mthick tissue sections. The streptavidin-biotin-peroxidase method was used following standard protocols. After deparaffinization and hydration, sections were subjected to antigen retrieval using EDTA + Tween 20 buffer $(\mathrm{pH}$ 8.0) and a decloaking chamber (Biocare Medical, Concord, CA, USA) for $15 \mathrm{~min}$ at $110{ }^{\circ} \mathrm{C}$. Endogenous avidin-biotin binding properties and endogenous peroxidase activity were blocked according to Miller et al (14). The sections were incubated in a humidity chamber at $25{ }^{\circ} \mathrm{C}$ for $2 \mathrm{~h}$, with the following primary antibodies: Ki-67 (ab16667, 1:50) and p53 (ab26, 1:50), purchased from Abcam (Cambridge, UK); smooth-muscle actin (SMA; CM 001C, 1:100), CK-19 (SKU 242, 1:100) and desmin (C036C, 1:100), from Biocare Medical; Bcl-2 (m0887, $1: 200)$, CK-8 (M3652, 1:100), CK-14 (sc-53253, 1:50), CK-18 (M7010, 1:200), p63 (M7247, 1:50) and vimentin (M0725, 1:100) from Dako North America Inc., (Carpentaria, CA, US); and calretinin (sc-365956, 1:150), CK-7 (sc-23876, 1:200), HHF35 (sc-53014, 1:100), and p16 (sc-8340, 1:100) from Santa Cruz Biotechnology (Dallas,
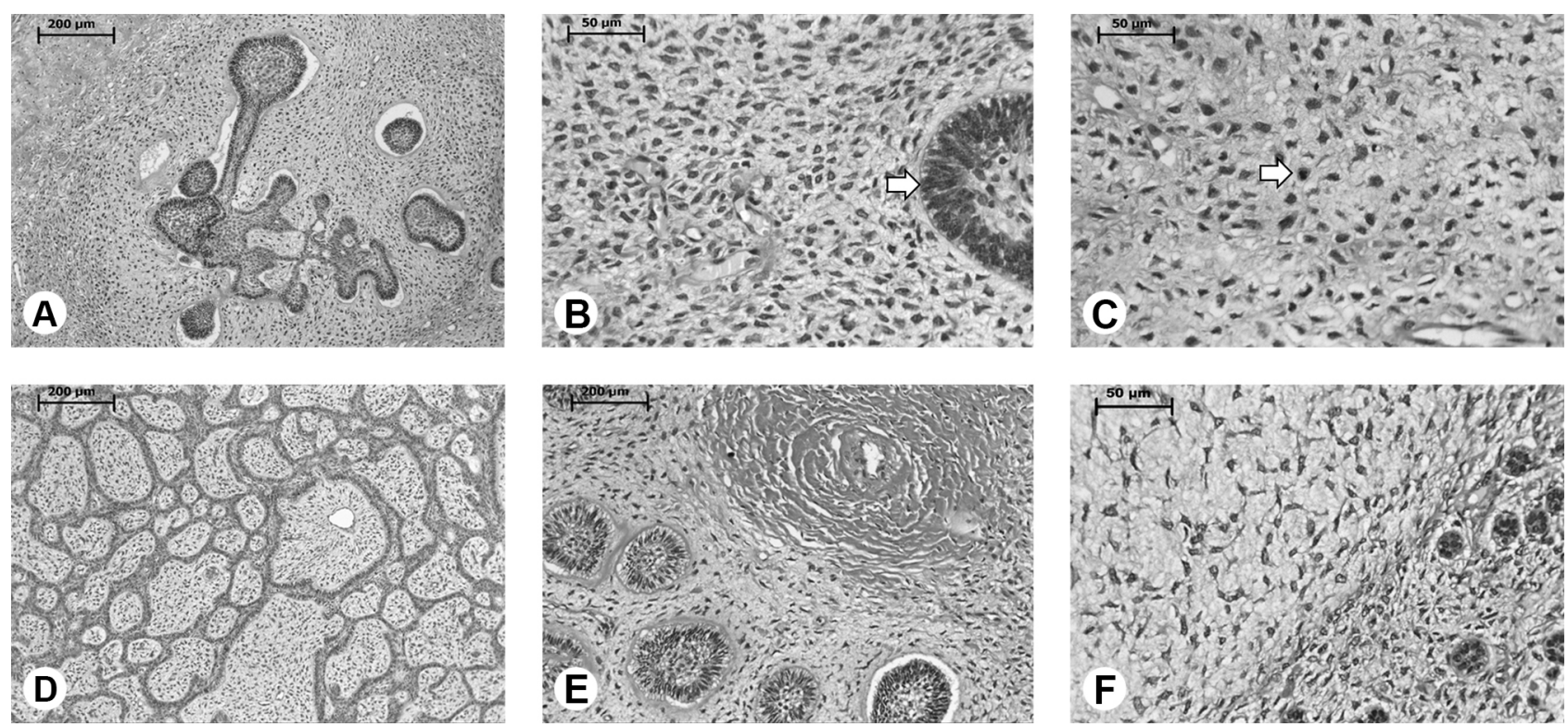

Figure 1: A) Tumor showing an ameloblastic fibroma-like pattern (hematoxylin and eosin staining, (HE), 10x). B) Marked pleomorphism in odontogenic ectomesenchyme adjacent to an epithelial island. Note basal hyperplasia and hyperchromatism on the epithelial compartment (arrow), (HE, 40x). C) Odontogenic ectomesenchyme showing high pleomorphism, hyperchromatism and mitotic figure (arrow). Note anisocariosis and anisocitose on mesenchymal malignant cells, (HE, 40x). D) Nests and cords of odontogenic epithelium in a highly cellular odontogenic ectomesenchyme, (HE, 10x). E) Tumoral stroma showing hyalinization, (HE, 40x). F) Tumoral mesenchyme demonstrating undifferentiated pulp mesenchymal cells and a more collagenous and fibrous stroma, (HE, 40x). 
TX, USA). For signal amplification and staining, was used the Starr Trek Universal HRP Detection System (Biocare Medical). Finally, sections were counterstained with Harris hematoxylin. As a negative control, primary antibodies were replaced with phosphate-buffered saline. Fragments of various human tissues were used as positive controls, in accordance with the manufacturer's guidelines.

Three of the authors (AML, JPSS, and CVR) evaluated

Table 1. Immunohistochemical data of the present case, Quickscores are presented inside brackets

\begin{tabular}{|c|c|c|c|c|}
\hline \multirow{2}{*}{ Antibody } & \multirow{2}{*}{ Dilution } & \multirow{2}{*}{ Positive controls } & \multicolumn{2}{|c|}{ Case 1} \\
\hline & & & Epithelial cells & Stromal cells \\
\hline Ki-67 & $1: 50$ & Colon carcinoma & 15.7 cells/HPF & 20.9 cells/HPF \\
\hline Bcl-2 & $1: 200$ & Breast carcinoma & Negative (0) & Negative (0) \\
\hline p16 & $1: 100$ & Squamous cell carcinoma & Diffuse C/N (6) & Diffuse $\mathrm{C} / \mathrm{N}(18)$ \\
\hline p53 & $1: 50$ & Squamous cell carcinoma & Diffuse C/N (12) & Diffuse C/N (6) \\
\hline p63 & $1: 50$ & Basal cell carcinoma & Diffuse N (18) & Diffuse N (6) \\
\hline Ck7 & $1: 200$ & Salivary gland & Negative (0) & Negative (0) \\
\hline Ck8 & $1: 100$ & Normal prostate & Diffuse C (4) & Negative (0) \\
\hline Ck14 & $1: 50$ & Normal skin & Diffuse C (6) & Negative (0) \\
\hline Ck18 & $1: 200$ & Normal colon & Negative (0) & Negative (0) \\
\hline Ck19 & $1: 100$ & Normal colon & Diffuse C (18) & Negative (0) \\
\hline AML & $1: 100$ & Normal colon & Negative (0) & Diffuse C (2) \\
\hline Vimentin & $1: 100$ & Normal colon & Negative (0) & Diffuse C/N(18) \\
\hline Desmin & $1: 100$ & Normal colon & Negative (0) & Negative (0) \\
\hline Calretinin & $1: 150$ & Ameloblastoma & Negative (0) & Negative (0) \\
\hline HHF35 & 1:100 & Normal colon & Negative (0) & Negative (0) \\
\hline
\end{tabular}

C: cytoplasmatic; HPF: high power field; N: nuclear. immunohistochemical staining using the Quick-Score method, according to Detre et al (15). The products are multiplicative quick-score and score values, ranging from 0 to 18 . For Ki-67 analysis, the mean number of positive cell nuclei in 10 consecutive high-power fields (HPFs) was determined.

Immunohistochemical studies (Table 1) showed high counts of Ki-67 in HPFs (Fig. 2A), mainly in stromal cells (mean, 20.9 cells/HPF; $20 \%$ of all cells). Most epithelial cells had small numbers of Ki-67-positive cells (15.7 cells/HPF; $\sim 10 \%$ of all cells). All compartments of the tumor were negative for $\mathrm{Bcl}-2$. The atypical mesenchymal cells showed strong diffuse nuclear and cytoplasmic reactivity for $p 16$, whereas the epithelial component showed only weak staining for this marker (Fig. 2C). However, the epithelial cells showed strong diffuse nuclear and cytoplasmic reactivity for p53 (Fig. 2B) and p63 (Fig. 2D) and the stromal cells were weakly positive. The benign ameloblastomatous component showed weak diffuse cytoplasmic reactivity for CK8 and CK14 (Fig. 2E and $F$, respectively), but strong CK19 cytoplasmic staining was apparent (Fig. $2 \mathrm{G}$ ). The stromal malignant component was positive for vimentin and SMA (Fig. $2 \mathrm{H})$. There was no reactivity for CK7, CK18, calretinin, fibronectin or desmin. The patient's healing process was uneventful and no sign of recurrence or metastasis has been observed during
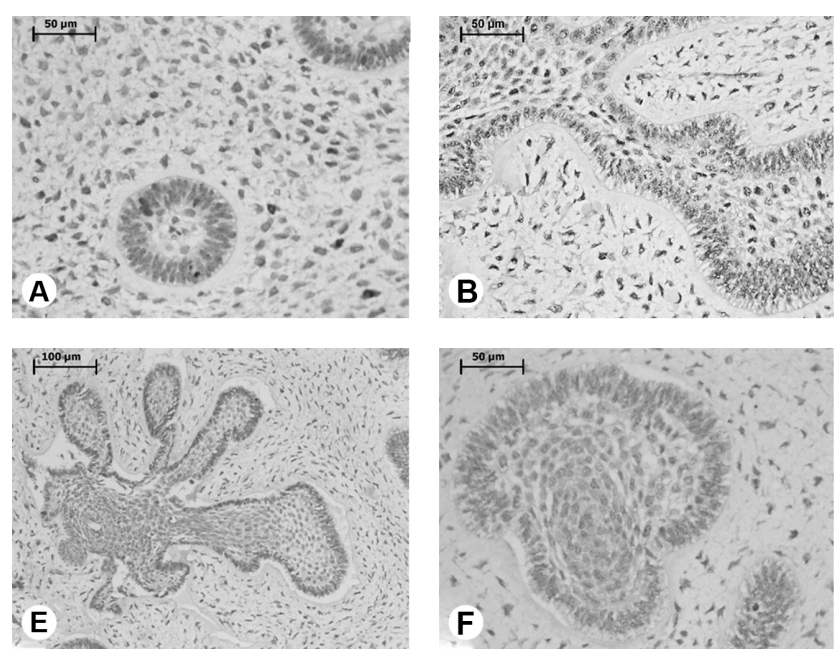
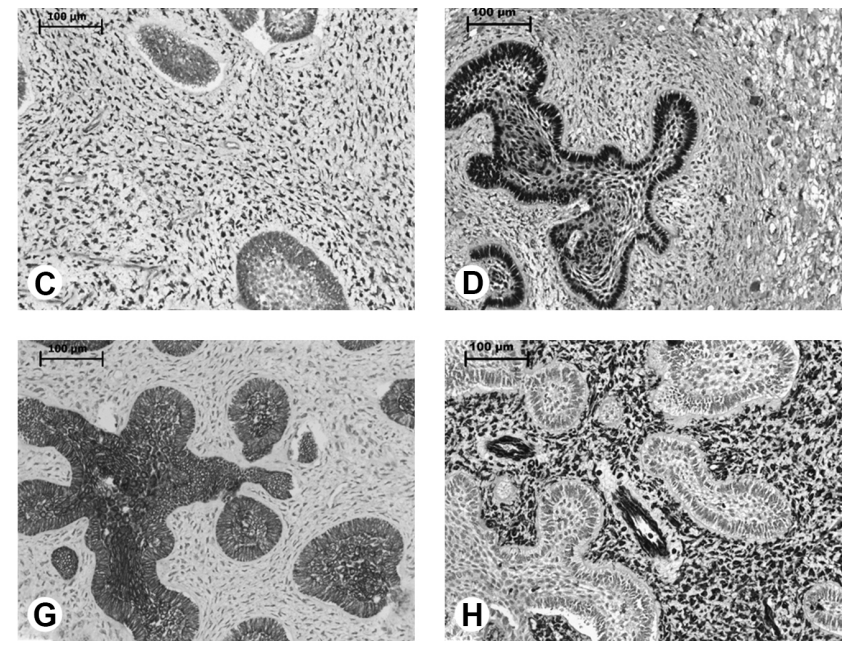

Figure 2. Immunohistochemical analysis of AFS; A) Ki-67 (40x); B) p53 (40x); C) p16 (20x); D) p63 (20x); E) Ck8 (20x); F) Ck14 (40x); G) Ck19 (20x) and H) Vimentin (20x). 
12 years of follow-up.

\section{Systematic Literature Review}

A systematic literature review was made using electronic databases (PubMed and LILACS) to identify relevant publications between 1880 and 2015 that included cases of AFS. The following search terms were used: "ameloblastic" AND "fibrosarcoma" OR "fibro-dentinosarcoma" OR "fibroodontosarcoma." Finally, a manual search was done by cross-referencing from the retrieved manuscripts. (4-6,913,16-113). Papers describing clinicopathological features similar to those described for AFS were included in the first instance $(4,5,9-13,16-25,28-30,32,34-39,42,43,45-65,67-$ $72,74-89,91,93,94,113)$.

Studies that could not be accessed and those with inconsistent or equivocal reporting of features, like suboptimal histological illustrations or unclear clinicopathological data, were excluded $(6,17-24,26$ $27,31,33,40,41,44,66,73,90,92)$. Data on sociodemographic characteristics, clinical features, treatment, follow-up, and outcomes were collected and tabulated for each study.

Descriptive statistics were used to assess the clinicopathological data. All collected information was considered in the overall survival analysis. Curves for different clinicopathological factors were traced using the Kaplan-Meier method and then compared using univariate analyses (log-rank test). The chi-square test was used to analyze any association between clinical and histomorphological factors. The Spearman rank correlation test was used to determine whether lesion size was correlated with evolution time. The significance level was set at 5\%. All analyses were performed using the GraphPad Prism software (v. 5.01; San Diego, CA, USA).

\section{Results}

The search strategy resulted in the identification of 119 cases in 88 articles $(4-6,9-13,16-94,113)$. Among them, 99 cases had clear and unequivocal histological documentation $(4,5,9-13,16-25,28-30,32,34-39,42,43,45-65,67-72,74-$ $89,91,93,94,113)$.

Tables 2 and 3 highlight the overall clinicopathological features of AFS from the literature and the present case report. Of these, $88(88.9 \%)$ cases were diagnosed as AFS, $(4,5,9-13,16-25,28-30,32,34-39,42,43,45-$ $65,67-72,74-89,91,93,94,113), 9(9.1 \%)$ as AFOS, $(25,28,38,46,58,59,76,81,84)$ and $2(2.0 \%)$ as AFDS $(13,45)$.

For the cases diagnosed as AFS, age ranged widely from 0.33 to 89 (mean, 28.1 \pm 16 ) years. Lesions usually affected the posterior mandible (59 cases, 67.1\%), without predilection for gender or ethnicity (male:female ratio, 1:0.8; white:non-white ratio, 1:0.8). Most of the lesions presented large (mean, $5.8 \pm 3.3 \mathrm{~cm})$, painful $(40 / 79,50.6 \%)$
Tables. Clinic-pathological and treatment data of the sample about ameloblastic fibrosarcoma, retrieved from international literature

\begin{tabular}{|c|c|}
\hline Number of cases & 99 cases \\
\hline \multirow{3}{*}{ Age } & Mean: $27.6 \pm 16$ yrs \\
\hline & Median: 24 yrs \\
\hline & Range: $0.33-89$ yrs \\
\hline \multirow{3}{*}{ Gender } & Male: 52 (54.2\%) \\
\hline & Female: $44(45.8 \%)$ \\
\hline & M:F ratio: $1: 0.8$ \\
\hline \multirow{3}{*}{ Skin color } & White: 26 (50.0\%) \\
\hline & Non-white: 26 (50.0\%) \\
\hline & W:NW ratio: $1: 1$ \\
\hline \multirow{3}{*}{ Size } & Mean: $5.8 \pm 3.2 \mathrm{~cm}$ \\
\hline & Median: $5.0 \mathrm{~cm}$ \\
\hline & Range: $0.7-14 \mathrm{~cm}$ \\
\hline \multirow{4}{*}{ Location } & Maxilla: 25 (25.3\%) \\
\hline & Mandible: 74 (74.4\%) \\
\hline & $\begin{array}{l}\text { Most common sub-site: Posterior } \\
\text { mandible: } 70(70.7 \%)\end{array}$ \\
\hline & Mx:Md ratio: $1: 3.0$ \\
\hline \multirow{2}{*}{ Evolution time } & Mean: $37.7 \pm 170.7$ months \\
\hline & Range: $0-1332$ months \\
\hline \multirow{3}{*}{ Signs and symptoms } & Swelling: 88/89 (98.9\%) \\
\hline & Pain: 48/89 (53.9\%) \\
\hline & Bleeding: 7/89 (7.9\%) \\
\hline \multirow{3}{*}{ Histological pattern } & Ameloblastic fibrossarcoma: 88/99 (88.9\%) \\
\hline & Ameloblastic odontosarcoma: 9/99 (9.1\%) \\
\hline & Ameloblastic dentinosarcoma: 2/99 (2.0\%) \\
\hline \multirow{2}{*}{ Surgical margins } & Positive: $10 / 40$ (25.0\%) \\
\hline & Negative: 30/40 (75.0\%) \\
\hline \multirow{2}{*}{ Regional metastasis } & $2 / 86(2.3 \%)$ \\
\hline & No predilection \\
\hline \multirow{2}{*}{ Distant metastasis } & $6 / 87(6.9 \%)$ \\
\hline & Lungs: $66.7 \%$ \\
\hline \multirow{2}{*}{ Local recurrence } & Present: 48/89 (54.0\%) \\
\hline & Absent: 41/89 (46.0\%) \\
\hline \multirow{3}{*}{ Treatment modalities } & ST: 86/90 (95.6\%) \\
\hline & RxT: 22/78 (28.2\%) \\
\hline & ChT: $14 / 78(17.9 \%)$ \\
\hline \multirow{2}{*}{ Follow up } & Mean: $52.0 \pm 65.2$ months \\
\hline & Range: $0-360$ months \\
\hline \multirow{3}{*}{ Imagiological border } & Well circumscribed: 19/53 (35.8\%) \\
\hline & Ill defined: 33/53 (62.3\%) \\
\hline & Without none involvement: 1/53 (1.9\%) \\
\hline \multirow{4}{*}{ Outcomes } & NED: 60/83 (72.3\%) \\
\hline & DOD: $17 / 83(20.5 \%)$ \\
\hline & DOC: $2 / 83(2.4 \%)$ \\
\hline & AWD: 4/83 (4.8\%) \\
\hline
\end{tabular}

AWD: alive with disease; ChT: chemotherapy; DOD: Died of disease; NED: no evidence of disease; RxT: radiotherapy; ST: surgical treatment. 
Table 3. Ameloblastic fibrosarcoma: comparison of median survival based on demographics, tumor characteristics and applied therapy, related with the case reports retrieved from English literature

\begin{tabular}{|c|c|c|c|}
\hline Variable $^{\mathrm{a}}$ & Subgroup & $\begin{array}{l}\text { Median } \\
\text { survival } \\
\text { rate (mo) }\end{array}$ & $\mathrm{p}$ value $^{\mathrm{b}}$ \\
\hline Overall & -- & & -- \\
\hline \multirow{2}{*}{ Age } & $<65$ years $(\mathrm{n}=79)$ & 228.0 & $<0.001$ \\
\hline & $\geq 65$ years $(\mathrm{n}=3)$ & 3.0 & \\
\hline \multirow{2}{*}{ Gender } & Male $(n=47)$ & 120.0 & 0.755 \\
\hline & Female $(n=33)$ & 228.0 & \\
\hline \multirow{2}{*}{ Skin color } & White $(n=26)$ & -- & 0.178 \\
\hline & Non-white $(\mathrm{n}=23)$ & 114.0 & \\
\hline \multirow{2}{*}{ Tumor size } & Less than $4 \mathrm{~cm}(\mathrm{n}=15)$ & 60.0 & 0.252 \\
\hline & More than $4 \mathrm{~cm}(\mathrm{n}=49)$ & -- & \\
\hline \multirow{2}{*}{ Site } & Maxilla ( $\mathrm{n}=21)$ & 114.0 & 0.161 \\
\hline & Mandible $(\mathrm{n}=61)$ & 228.0 & \\
\hline \multirow{2}{*}{ Symptomatology (Swelling) } & Present $(\mathrm{n}=78)$ & 228.0 & 0.215 \\
\hline & Absent $(\mathrm{n}=1)$ & -- & \\
\hline \multirow{2}{*}{ Symptomatology (Pain) } & Present $(n=45)$ & 228.0 & 0.75 \\
\hline & Absent $(n=34)$ & 120.0 & \\
\hline \multirow{2}{*}{ Symptomatology (Bleeding) } & Present $(n=7)$ & -- & 0.407 \\
\hline & Absent $(\mathrm{n}=72)$ & 120.0 & \\
\hline \multirow{2}{*}{ Complaining time } & Less than 40 months $(\mathrm{n}=48)$ & 120.0 & 0.345 \\
\hline & More than 40 months $(\mathrm{n}=7)$ & -- & \\
\hline \multirow{3}{*}{ Histological pattern } & $\begin{array}{c}\text { Ameloblastic } \\
\text { fibrosarcoma }(n=73)\end{array}$ & 228.0 & 0.371 \\
\hline & $\begin{array}{c}\text { Ameloblastic } \\
\text { odontosarcoma }(\mathrm{n}=8)\end{array}$ & 43.0 & \\
\hline & $\begin{array}{c}\text { Ameloblastic } \\
\text { dentinosarcoma }(n=1)\end{array}$ & -- & \\
\hline \multirow{2}{*}{ Hard tissue deposition } & Present $(\mathrm{n}=19)$ & 114.0 & 0.167 \\
\hline & Absent $(n=58)$ & 228.0 & \\
\hline \multirow{2}{*}{ Surgical margins } & Free $(\mathrm{n}=28)$ & -- & 0.854 \\
\hline & Committed $(\mathrm{n}=10)$ & 228.0 & \\
\hline \multirow{2}{*}{ Regional metastasis } & Present $(n=2)$ & 43.0 & $\underline{0.034}$ \\
\hline & Absent $(\mathrm{n}=77)$ & 228.0 & \\
\hline \multirow{2}{*}{ Distant metastasis } & Present $(n=6)$ & 43.0 & $\underline{0.001}$ \\
\hline & Absent $(\mathrm{n}=74)$ & 228.0 & \\
\hline \multirow{2}{*}{ Local recurrence } & Present $(n=44)$ & 120.0 & $\underline{0.002}$ \\
\hline & Absent $(\mathrm{n}=36)$ & & \\
\hline \multirow{2}{*}{ First surgery employed } & Conservative approach $(\mathrm{n}=34)$ & 120.0 & $\underline{0.049}$ \\
\hline & Aggressive approach $(\mathrm{n}=44)$ & -- & \\
\hline \multirow{2}{*}{ Radiotherapy } & Given $(n=21)$ & 60.0 & 0,119 \\
\hline & Not given $(\mathrm{n}=49)$ & -- & \\
\hline \multirow{2}{*}{ Chemotherapy } & Given $(n=13)$ & 60.0 & 0.281 \\
\hline & Not given $(n=58)$ & 228.0 & \\
\hline
\end{tabular}

aOnly valid information; bog-rank test. and persistent swellings with a mean complaint time of $42.4 \pm 184.5$ months. Radiographically, lesions were radiolucent with ill-defined margins in 31/42 (73.8\%) cases and well-defined margins in 11/42 (26.2\%) cases. Only one peripheral lesion was reported and the bone was free of invasion. Most of the lesions were diagnosed as de novo malignancies $(44 / 76,57.9 \%)$. The remaining lesions were described by the authors as malignant transformations of $\mathrm{AF}$ and ameloblastic fibro-odontoma (32/76, 42.1\%). Out of 74 cases, 11 (14.9\%) exhibited deposition of hard tissue, mainly described as dentinoid and enameloid materials. Surgical treatment was the primary therapy in most cases. After surgical procedures, positive margins were seen in 10/36 (27.8\%) patients. In 21/70 (30.0\%) cases, postoperative radiotherapy was performed. Chemotherapy was administered to $12 / 71$ (16.9\%) patients. Despite this treatment, local recurrence was observed in 48/89 (54.0\%) informative cases, with a mean time of $42.8 \pm 69.8$ months. There were regional and distant metastases reported in less than $10.0 \%$ of cases. Metastasis appeared 7 months after the first appointment in $42.4 \pm 48$ cases on average. The overall mortality rate was $20.3 \%$ (15/74).

The 9 cases diagnosed as AFOS affected the posterior mandible (100.0\%), mostly in female patients $(5 / 8,62.5 \%)$, with a mean age of $21.3 \pm 11.8$ years. Swelling was present in all cases and pain was the chief complaint in six of eight (75.0\%) cases. Six of the eight lesions were considered as de novo malignancies; the remaining two were considered as malignant transformations of one AF and one ameloblastic fibroodontoma. Most of these patients were managed surgically $(8 / 9,88.9 \%)$; from them, initial aggressive surgical treatment was performed in five of eight (62.5\%) cases. Only three patients received complementary therapy (2/8 chemotherapy and $1 / 8$ radiotherapy). There were recurrent primary tumors in four of nine (44.4\%) cases. Regional and distant metastatic foci were diagnosed in only one patient (46). After a mean follow-up period of $19.9 \pm 12.4$ months, only $2 / 8$ patients died of the 
disease; the remaining patients (6/8) had no evidence of disease at the last recorded appointment.

Only two cases were diagnosed with AFDS, $(13,45)$ and both involved the posterior mandibles of non-white male patients in the third decade of life (mean, $26 \pm 1.4$ years). Both patients complained of swelling and pain. One case was diagnosed as de novo and the other was diagnosed as malignant transformation of a previous AF. The patients received initial aggressive surgical management. None of these cases evolved with relapse or metastatic disease. Treatment was prescribed for only one case and the patient was disease-free for 18 months after diagnosis.

An overall survival analysis was performed for all 99 cases. The median overall survival time was 228 months, and the overall 5-, 10- and 20-year survival rates were $71.3 \%, 53.3 \%$, and $26.6 \%$, respectively (Fig. 3A). Results of a univariate overall survival analysis are in Table 3. Statistically significant associations were identified for the following parameters: age (Fig. 3B), regional metastasis (Fig. 3C), distant metastasis (Fig. 3D), local recurrence (Fig. 3E) and first surgical treatment (Fig. 3F). Patients treated with adjuvant therapies (radiotherapy and/or chemotherapy) had a very low overall median survival ratio (Table 3 ).

\section{Discussion}

According to a more extensive series of OTs, MOTs accounted for $0.1-6.0 \%$ of these tumors; most were carcinomas and odontogenic sarcomas, including AFS, AFDS and AFOS, represented less than $0.2 \%$ of cases. AFS is the most common of them (66,114-117). In Brazilian series, the reported frequency of AFS is up to $1.0 \%$ of OTs $(3,117-120)$

The WHO's odontogenic tumor classification describes AFS as being of primary (de novo lesion) and secondary (from benign AF) types $(1,4,5)$. Because of the secondary types (88), initial diagnosis of a malignant phenotype is not always easy. As anaplasia is not distributed uniformly throughout the tumor, definitive diagnosis can be made only from surgically removed pieces, as in the present case. This information is required for the detailed evaluation of the clinical history and radiographic aspects to identify preoperatively aspects that may help the surgeon choose a more representative area to be biopsied or even to make multiple biopsies. However, in the case of clinicoradiographic evidence of an aggressive tumor, serial sampling of surgical specimens should be performed to look for a histologically malignant phenotype.

Clinically, most AFS are similar to $\mathrm{AF}$, but characteristics
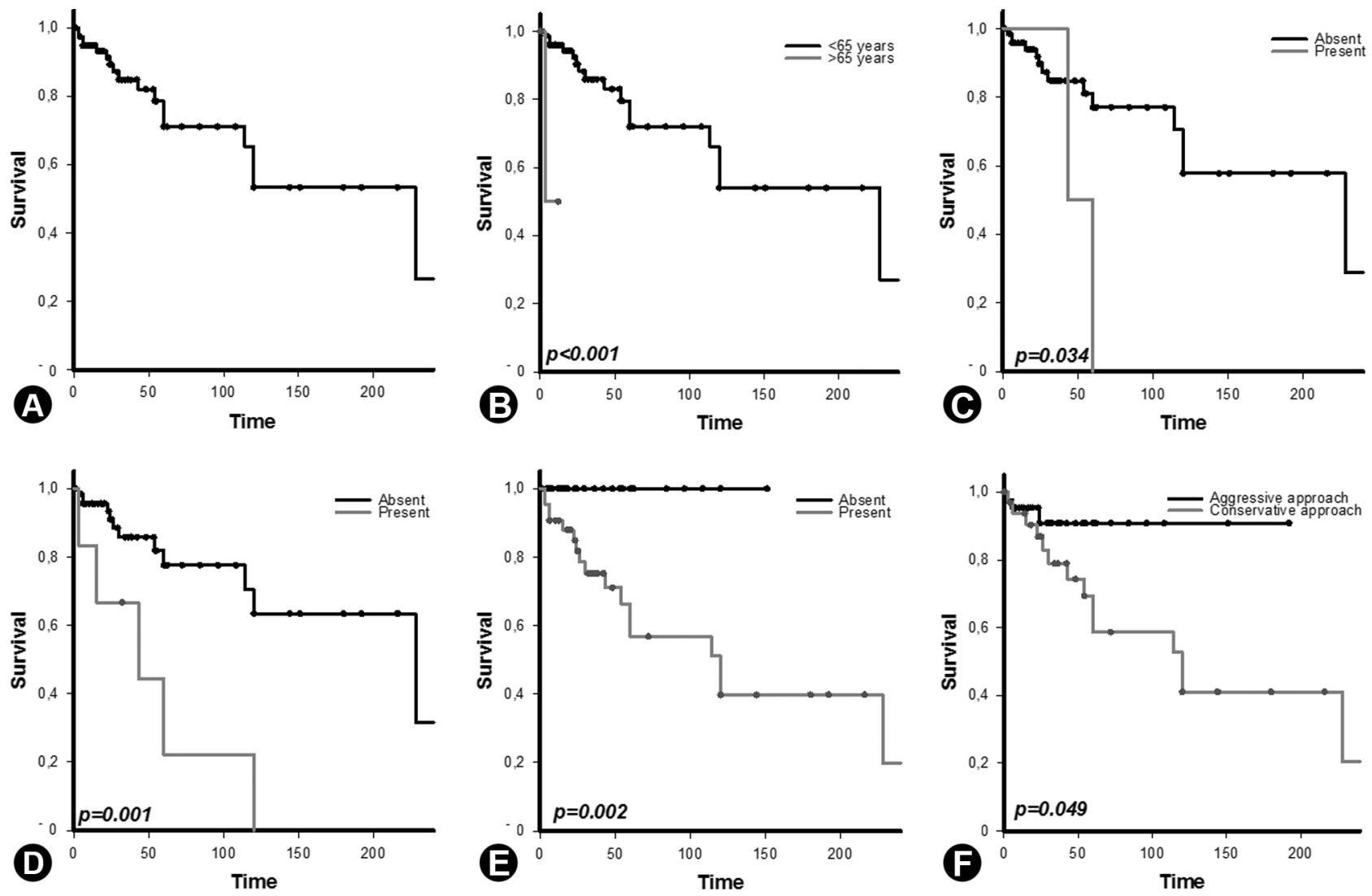

Figure 3. Overall Kaplan-Meier survival curve for patients with AFS (A) and stratified according to age (B), regional metastasis (C), distant metastasis (D), local recurrence (E) and the employed first surgery (F). 
of aggressive behavior are always identified, as seen in the present case. Based on the present review, AFS is a locally invasive neoplasm predominantly affecting the mandibles of male individuals with a wide age range (4 months to 89 years). The most common clinical features of AFS are facial swelling, often accompanied by pain. Paresthesia, dysesthesia and ulcers are sometimes reported $(5,37,47,67)$. Radiologically, AFS appears as a uni- or multilocular radiolucent mass with an ill-defined border, frequently causing gross expansion, thinning or even rupture of the cortical bone (88). However, cases with well-defined radiolucency are uncommon (72). Maxillary lesions tend to show antral involvement with apparent erosion of the sinus walls and a propensity to invade adjacent soft tissues, the base of the cranium and intracranial and orbital tissues $(12,62,78)$.

The gold standard for the treatment of AFS is radical surgery with clear margins $(5,89)$. Neck dissection is not usually indicated, because regional lymph node metastases are seldom identified. Postoperative radiotherapy at a dose of 50-60 Gy $(10,65)$ was sometimes used, with no recurrence during the follow-up period (4). In a few described cases, adjuvant chemotherapy was used, with inconclusive results (4).

Local recurrence was commonly seen, in 48/89 (54.0\%) cases (5). However, regional and/or distant metastases are extremely rare (4) and were histologically confirmed in the mediastinal lymph nodes, liver and lung ( 9.0\%) (53). According to this review, the mortality rate is quite low ( 20\%) for patients with AFS.

In described case, the patient was treated by mandibulectomy, with no adjuvant therapy. The postoperative period was uneventful and the patient is disease-free, with no metastasis, after 12 years of follow-up. Because of such outcomes, some authors are doubtful of the prognostic benefit related to complementary chemoand/or radiotherapy for these lesions $(71,74)$. Cases first treated with a conservative approach have demonstrated lower overall survival, mainly because of multiple relapses and the involvement of other structures (Table 3 and Fig. 3). The present case clearly demonstrates the importance of aggressive initial treatment, as the patient remained disease-free after only one surgical procedure.

Immunohistochemical studies may facilitate diagnosis of these lesions, given that Ki-67, PCNA and p53 were found expressed at higher levels within the sarcomatous component of the AFS, whereas they are absent or expressed at lower levels in $\operatorname{AF}(5,12,62,69,79,89,101,113,123)$. Results obtained from several papers $(4,5,69,79,82,88,89,113)$ revealed that Ki-67 was overexpressed (highly diffuse positivity) in the malignant mesenchymal portion of AFS, compared with AF. When Ki-67 was quantified, positivity rates ranged from $13.5 \%$ to $60.0 \%$ for the malignant mesenchymal component. Although no established cutoff value for Ki-67 positivity has been reported in the literature, the present case is within the interval of $\mathrm{Ki}-67$ expressed in malignant lesions ( $20.0 \%)$, suggesting that proliferative factors, in association with histopathological features, may be useful markers for the identification of malignant cases $(4,5,69,79,88,89,113)$.

Reports have also indicated that the epithelial component is not associated with AF or AFS growth. However, evidence of epithelial proliferative activity has been described in AFS $(4,5,69,79,88,89,113)$. In this study case, for example, marked hyperplasia of ameloblasticlike cells was observed; however, positivity for Ki-67 was found to be less than in the mesenchymal component. Change in embryonic mesenchymal density is an important phenomenon that induces epithelial modifications during odontogenesis. Epithelial proliferation in AFS may represent an atavistic behavior of the epithelium in front of a dense neoplastic stroma. The presence of differences in proliferative potential between epithelial and mesenchymal AFS components is relevant for the differentiation of AFS from odontogenic carcinosarcoma, in which the epithelial and mesenchymal components are similarly proliferative and anaplastic $(101,121,122)$.

Disruption in the mechanisms of control cell growth is a hallmark of cancer, which occur mainly due to derangement of the cell cycle checkpoints. A family of cyclins, cyclindependent kinases (CDKs) and their inhibitors (CDKIs) controls the CELL cycle. These proteins have been used as biological behavior and prognosis for different neoplasia. p53 was the most studied tumor suppression protein, which binds DNA and activates expression of several genes, that culminates with inhibition of cell cycle. Recent studies about AF malignant transformation linked such evolution to the acquisition of oncogenic aberrations in TP53. These alterations have been shown by loss of heterozygosity and immunohistochemistry studies and the present data reinforce such evidences $(75,123)$.

Other important regulatory cell cycle proteins are p63 and $p 16$. $p 63$ protein has been recognized as a member of the p53 family and is also responsible for cell cycle control. p16 protein is a tumor suppressor gene protein, which is a CDKI that regulates the G1-S phase of the cell cycle. Studies regarding $p 63$ and $p 16$ on the pathogenesis of AFS are apparently elusive. In this study, p16 and p63 were also found highly expressed, which confirms that deregulation in cell cycle controlling proteins are common events in AFS pathogenesis $(1,88,105)$.

Absence of CK-7, CK-8 and CK-18, and high expression CK-14 and CK-19 support the odontogenic origin of the epithelial counterpart. Although cell proliferation is up- 
regulated in the sarcomatous component, it does not appear to affect the differentiation status of the ameloblastic epithelium in AFS. The malignant sarcomatous component showed positivity only for vimentin, demonstrating no apparent transdifferentiation signal. More studies based on a comparative approach are required to improve the significance of the present findings on the pathogenesis and progression of AFS.

According to the WHO's classification, (1) AFS, AFDS and $\mathrm{AFOS}$ represent distinct lesions $(1,88,105)$. However, these lesions appear to represent different stages of tumor parenchyma differentiation, reflecting the complex inductive phenomena involving odontogenic epithelium and ectomesenchyme. Variations in tumor parenchyma differentiation seem to have no influence on clinical behavior, as the lesions show very similar clinicdemographic aspects and are associated with similar overall median survival rates, as described in this review. Data from the present review argue against the influence of the tumor odontogenic matrix or hard-tissue deposition on the nature of odontogenic sarcomatous lesions. It thus agrees with other reports that AFS, AFDS and AFOS should not be classified as separate nosological entities $(4,9,13,3$ $0,37,43,62,69,104,124)$.

In conclusion, the data compiled to date demonstrate that AFS is a low-grade mesenchymal odontogenic malignant neoplasia with a predilection for the posterior mandible, occurring mainly in the third decade of life. The histopathological features of AFS suggest that this entity has pathogenetic relationships with AFDS and AFOS. There was some suggestive morphological and behavioral evidence of similarities among these lesions. For the authors, segregation of these lesions based on their mesenchymal inductive potentials seems to be inappropriate. This study reinforces the necessity of treating AFS with an aggressive surgical approach, with no need for other complementary therapies.

\section{Resumo}

Aqui é descrito um caso de fibrossarcoma ameloblástico afetando região posterior da mandibula de uma mulher. Após o tratamento, a paciente ficou livre da doença durante os 12 anos de acompanhamento. Foi realizado imunohistoquimica para marcadores epiteliais, mesenquimais e do ciclo celular. Além disso, uma revisão sistemática de literatura também foi realizada, na tentativa de descobrir as características clínico-demográficas e fatores prognósticos da lesão. 88/99 casos foram diagnosticados como fibrossarcoma ameloblastico, 9/99 como fibro-odontosarcoma ameloblastico e 2/99 como fibrodentinosarcoma ameloblastico. Todas estas lesões exibem caracteristicas clínico-demográficas e prognósticos muito semelhantes. Além disso, esta revisão forneceu evidências de que primeiro tratamento, metástases regionais, metástases à distância e recorrência local são valores prognósticos significativos para lesões odontogênicas mesenquimais malignas. A análise imunohistoquimica demonstrou elevada marcação positiva em células do estroma para Ki-67 (média de 20,9 células/HPF). As células epiteliais exibiram forte marcação para p53, p63 e citoqueratina 19. A segregação entre fibrosarcoma ameloblastico, fibrodentinosarcoma ameloblastico e fibro-odontosarcoma ameloblastico é ilógica, uma vez que todas essas lesões têm predileções e resultados semelhantes.

\section{Acknowledgements}

Financial support from the Brazilian governmental agencies Fundação de Amparo a Pesquisa do Estado de Minas Gerais (FAPEMIG) and Conselho Nacional de Desenvolvimento Científico e Tecnológico (CNPq).

\section{References}

1. Carlos R, Altini M, Takeda Y. Odontogenic sarcomas. In: Barnes L, Eveson JW, Reichart P, Sidransky D, editors. World Health Organization Classification of Tumours. Pathology and Genetics of Head and Neck Tumours. Lyon: IARC Press; 2005;p.294-295.

2. Henriques A, Cazal C, Fonsêca D. Considerations regarding the epithelial odontogenic tumor classification and biological behavior: a literature review. Rev. Bras. Cancerol. 2009;55:175-184

3. Servato JP, Prieto-Oliveira P, Faria PR de, Loyola AM, Cardoso SV. Odontogenic tumours: 240 cases diagnosed over 31 years at a Brazilian university and a review of international literature. Int J Oral Maxillofac Surg 2013;42:288-293.

4. Lai J, Blanas N, Higgins K, Klieb H. Ameloblastic fibrosarcoma: report of a case, study of immunophenotype, and comprehensive review of the literature. J Oral Maxillofac Surg 2012;70:20072012.

5. Loya-Solis A, González-Colunga KJ, Pérez-Rodríguez CM, RamírezOchoa NS, Ceceñas-Falcón L, Barboza-Quintana 0. Ameloblastic fibrosarcoma of the mandible: a case report and brief review of the literature. Case Rep Pathol 2015;2015:245026.

6. Heath, C.: Five cases of tumor of jaws treated by excision. Brit M J 1887;1:777-779.

7. Pindborg Jj; Kramer IRH . Histological typing of odontogenic tumors, jaw cysts, and allied lesions. 1st ed. Berlin: Springer Verlag; 1971:p.3637.

8. Kramer IRH, Pindborg JJ, Shear M. International histological classification of tumours: histological typing of odontogenic tumows. 2nd ed. Heidelberg: Springer Verlag; 1992,p:26-27.

9. Muller S, Parker DC, Kapadia SB, Budnick SD, Barnes EL. Ameloblastic fibrosarcoma of the jaws. A clinicopathologic and DNA analysis of five cases and review of the literature with discussion of its relationship to ameloblastic fibroma. Oral Surg Oral Med Oral Pathol Oral Radiol Endod 1995;79:469-477.

10. Kobayashi K, Murakami R, Fujii T, Hirano A. Malignant transformation of ameloblastic fibroma to ameloblastic fibrosarcoma: case report and review of the literature. J Craniomaxillofac Surg 2005;33:352-355.

11. Dallera P, Bertoni F, Marchetti C, Bacchini P, Campobassi A. Ameloblastic fibrosarcoma of the jaw: report of five cases. J Craniomaxillofac Surg 1994;22:349-354.

12. Zabolinejad N, Hiradfar M, Anvari K, Razavi AS. Ameloblastic fibrosarcoma of the maxillary sinus in an infant: a case report with long-term follow-up. J Pediatr Surg 2008;43:e5-8.

13. Altini M, Thompson SH, Lownie JF, Berezowski BB. Ameloblastic sarcoma of the mandible. J Oral Maxillofac Surg 1985;43:789-794.

14. Miller RT, Kubier P, Reynolds B, Henry T, Turnbow H. Blocking of endogenous avidin-binding activity in immunohistochemistry: the use of skim milk as an economical and effective substitute for commercial biotin solutions. AIMM 1999;7:63-65.

15. Detre $S$, Saclani Jotti G, Dowsett M. A "quickscore" method for immunohistochemical semiquantitation: validation for oestrogen receptor in breast carcinomas. J Clin Pathol 1995;48:876-878.

16. Eve, F. Lecture on pathology and treatment of tumours jaws; delivered at Medical Graduate's College and Polyclinic. Brit M J 1907;1:15251532.

17. L'Esperance E. A preliminary report of eight cases of adamantinoma. Proc N Y Path Soc 1910;10:136

18. Krompecher E. Zur Histogenese und morphologie der adamantinome und sonstiger kiefergeschwulste. Beitr Pathol Nat 1918;64:165-197.

19. Papadimitriou B. Zur histologie und histogenese des adamantinoms. 
Bruns Beitr Klin Chir 1928;144:556-573.

20. Korte F. Zwei differential diagnostisch wichtige Unterkiefertumoren, Adamantinoma sarkomatodes und Wurzelzyste des Unterkiefers. Thesis. Quakenbruck, Germany. T. Kleinert. 1929.

21. Kegel R. F. C.: Adamantine epithelioma. Arch. Surg. 1932;25:498-528.

22. Wigdortschik W.: Beitrage zur Lehre von den Adamantinomen. Thesis. Riga, Latvia. Splendid. 1932.

23. Hauenstein K. Zur wertung und diagnostik der adamantinomartigen kiefertumoren. Dtsch Zahn Mund Kieferheilkd 1937;4:387-406.

24. Emminger E. Kenntnis der malignen adamantinome. Z Stomatol 1946;43:356-370.

25. Thoma KH. The pathogenesis of the odontogenic tumors. Oral Surg Oral Med Oral Pathol 1951;4:1262-1280.

26. Hertz J. Adamantinoma: studies in histopathology and prognosis. Acta Med Scand 1952;142:529-556.

27. Kelescian G.: Relievi istologici sul parenchiima degli adamantinoma in rapporto allo stroma. clinica odontojatrica dell'università di Ferrara. Bologna, Italy. Officina d'Arte Grafica Cacciari. 1955;28.

28. Villa VG. Ameloblastic sarcoma in the mandible. Oral Surg Oral Med Oral Pathol 1955;8:123-129.

29. Pindborg JJ. Ameloblastic sarcoma in the maxilla. Report of a case. Cancer 1960;13:917-920.

30. Cina MT, Dahlin DC, Gores RJ. Ameloblastic sarcoma. Report of two cases. Oral Surg Oral Med Oral Patho. 1962;15:696-700.

31. Muroya K, Shigematsu H. A case of malignant odontogenic mixed tumor. Trans Soc Pathol Jpn 1962;51:477-484.

32. Cataldo $E$, Nathanson N, Shklar G. Ameloblastic sarcoma of the mandible. Oral Surg Oral Med Oral Pathol. 1963;16:953-957.

33. Tahsinoglu M, Ozymerzifonlu S. Ameloblastick odontosarkoma. OdontStomatol (Istanbul) 1964;3:14-22.

34. Hogeman KE, Willmar K. Giant ameloblastic tumours of the lower jaw.

Report of three reconstructed cases. Acta Chir Scand 1966;131:236248.

35. Peychl L, Sazama L. Adamantinosarcoma of the maxilla. (Report of a case). Neoplasma 1971;18:403-406.

36. Mori M, Shimozato T, Kawano S, Kawakatsu K. Ameloblastic fibroma and ameloblastic sarcoma--a report of the cases, histopathology and histochemistry. J Osaka Univ Dent Sch 1972;12:91-107.

37. Leider AS, Nelson JF, TrodahI JN. Ameloblastic fibrosarcoma of the jaws. Oral Surg Oral Med Oral Pathol 1972;33:559-569.

38. Forman G, Garrett J. Ameloblastic sarcoma: report of case. J Oral Surg 1972;30:50-54.

39. Hatzifotiadis D, Economou A. Ameloblastic sarcoma in the maxilla--a case report. J Maxillofac Surg 1973;1:62-64.

40. Motegi K, Banba S, Totsuka M, Michi K, Yamazato S. [Ameloblastic sarcoma of the maxilla: report of a case (author's transl)]. Nihon Koku Geka Gakkai Zasshi 1975;21:176-179.

41. Remagen W, Prein J, Schafroth G, Schafroth U. [Proceedings: Ameloblastic fibroma and its sarcomatous degeneration]. Verh Dtsch Ges Pathol 1975;59:489.

42. Goldstein G, Parker FP, Hugh GS. Ameloblastic sarcoma: pathogenesis and treatment with chemotherapy. Cancer 1976;37:1673-1678.

43. Eda S, Saito T, Morimura G, Shindo O, Yanagisawa Y. A case of ameloblastic fibrosarcoma, with an electron-microscopic observation. Bull Tokyo Dent Coll 1976;17:11-25

44. Matsumura T, Kinoshita F, Hasegawa K, Kawakatsu K, Kawai N. Report of a case of ameloblastic sarcoma. Jpn J Oral Surg 1976;22:153.

45. Altini M, Smith I. Ameloblastic dentinosarcoma- a case report. Int J Oral Surg 1976;5:142-147.

46. Howell RM, Burkes EJ. Malignant transformation of ameloblastic fibro-odontoma to ameloblastic fibrosarcoma. Oral Surg Oral Med Oral Pathol 1977;43:391-401.

47. Adekeye EO, Edwards MB, Goubran GF. Ameloblastic fibrosarcoma. Report of a case in a Nigerian. Oral Surg Oral Med Oral Pathol 1978;46:254-259

48. Reichart PA, Zobl H. Transformation of ameloblastic fibroma to fibrosarcoma. Int J Oral Surg 1978;7:503-507.

49. Prein J, Remagen W, Spiessl B, Schafroth U. Ameloblastic fibroma and its sarcomatous transformation. Pathol Res Pract 1979;166:123-130.
50. Daramola JO, Ajagbe HA, Oluwasanmi JO, Akinyemi 00, Samuel I. Ameloblastic sarcoma of the mandible: report of case. J Oral Surg 1979;37:432-435.

51. Iwasa T. Ameloblastic fibrosarcoma of the mandible: Report of a case. Jpn J Oral Surg. 1981;27:1419.

52. Tahsinoglu M, Cilingiroglu K, Erseven G, Cologlu AS. Ameloblastic sarcoma: a case report. Mersin Universitesi Egitim Fakultesi Dergisi 1981:12-17.

53. Chomette G, Auriol M, Guilbert F, Delcourt A. Ameloblastic fibrosarcoma of the jaws--report of three cases. Clinico-pathologic, histoenzymological and ultrastructural study. Pathol Res Pract 1983;178:40-47. Doi: 10.1016/S0344-0338(83)80083-1.

54. Nasu M, Matsubara O, Yamamoto H. Ameloblastic fibrosarcoma: an ultrastructural study of the mesenchymal component. J. Oral Pathol 1984;13:178-187.

55. Takeda Y, Kaneko R, Suzuki A. Ameloblastic fibrosarcoma in the maxilla, malignant transformation of ameloblastic fibroma. Virchows Arch A Pathol Anat Histopathol 1984;404:253-263.

56. Yamamoto $\mathrm{H}$, Caselitz J, Kozawa Y. Ameloblastic fibrosarcoma of the right mandible: immunohistochemical and electron microscopical investigations on one case, and a review of the literature. J. Oral Pathol 1987;16:450-455.

57. Wood RM, Markle TL, Barker BF, Hiatt WR. Ameloblastic fibrosarcoma. Oral Surg Oral Med Oral Pathol 1988;66:74-77.

58. Phillips VM, Grotepass FW, Hendricks R. Ameloblastic odontosarcoma with epithelial atypia: a case report. Br J Oral Maxillofac Surg 1988;26:45-51.

59. Takeda $Y$, Kuroda M, Suzuki A. Ameloblastic odontosarcoma (ameloblastic fibro-odontosarcoma) in the mandible. Acta Pathol Jpn 1990;40:832-837.

60. Sözeri B, Ataman M, Ruacan S, Gedikoglu G. Ameloblastic fibrosarcoma. Int J Pediatr Otorhinolaryngol 1993;25:255-259.

61. Park HR, Shin KB, Sol MY, Suh KS, Lee SK. A highly malignant ameloblastic fibrosarcoma. Report of a case. Oral Surg Oral Med Oral Pathol Oral Radiol Endod 1995;79:478-481.

62. Tajima Y, Utsumi N, Suzuki S, Fujita K, Takahashi H. Ameloblastic fibrosarcoma arising de novo in the maxilla. Pathol Int 1997;47:564568.

63. Nogueira T de O, Carvalho YR, Rosa LE, Santos LM Dos. Possible malignant transformation of an ameloblastic fibroma to ameloblastic fibrosarcoma: a case report. J Oral Maxillofac Surg 1997;55:180-182.

64. Singh I, Yadav SP, Kalra GS, Sen R, Gathwala L. Ameloblastic sarcoma with diverse mesenchymal differentiation. Indian J Otolaryngol Head Neck Surg 1997;49:57-59. Doi: 10.1007/BF02991716.

65. DeNittis AS, Stambaugh MD, Looby C. Ameloblastic fibrosarcoma of the maxilla: report of a case. J Oral Maxillofac Surg 1998;56:672-675.

66. Lu Y, Takata T, Wang L, Zhou Z, Wu L, Zhao M, Nikai H. [An immunohistochemical study of the proliferating activity of ameloblastic fibroma and ameloblastic fibrosarcoma]. Hua Xi Yi Ke Da Xue Xue Bao 1998;29:390-393.

67. Hayashi Y, Tohnai I, Ueda M, Nagasaka T. Sarcomatous overgrowth in recurrent ameloblastic fibrosarcoma. Oral Oncol 1999;35:346-348.

68. Bregni RC, Taylor AM, Garcia AM. Ameloblastic fibrosarcoma of the mandible: report of two cases and review of the literature. J Oral Pathol Med. 2001;30:316-320.

69. Huguet $\mathrm{P}$, Castellví J, Avila M, Alejo, M, Autonell F, Basas $\mathrm{C}$, et al.. Ameloblastic fibrosarcoma: report of a case. Immunohistochemical study and review of the literature. Med Oral 2001;6:173-179.

70. Dufau J-PP, Paume P, Soulard R, Gros P. [Peripheral ameloblastic fibrosarcoma]. Ann Pathol 2002;22:310-313.

71. Mosqueda Taylor A, Meneses García A, Ruíz Godoy Rivera LM, Suárez Roa M d de L, Luna Ortiz K. Malignant odontogenic tumors. $A$ retrospective and collaborative study of seven cases. Med Oral 2003;8:110-121.

72. Batista de Paula AM, Costa Neto JQO da, Silva Gusmão E da, Guimarães Santos FB, Gomez RS. Immunolocalization of the p53 protein in a case of ameloblastic fibrosarcoma. J Oral Maxillofac Surg 2003;61:256-258. 73. Yamaguchi S, Nagasawa H, Suzuki T, Fujii, E, Iwaki, H, Takagi, M, et al.. Sarcomas of the oral and maxillofacial region: a review of 32 
cases in 25 years. Clin Oral Investig 2004:8:52-55.

74. Lee 0-JJ, Kim HJ, Lee BK, Cho K-JJ. CD34 expressing ameloblastic fibrosarcoma arising in the maxilla: a new finding. J Oral Pathol Med 2005;34:318-320.

75. Williams MD, Hanna EY, El-Naggar AK. Anaplastic ameloblastic fibrosarcoma arising from recurrent ameloblastic fibroma: restricted molecular abnormalities of certain genes to the malignant transformation. Oral Surg Oral Med Oral Pathol Oral Radiol Endod 2007;104:72-75. Doi: 10.1016/j.tripleo.2006.07.013.

76. Mainenti $\mathrm{P}$, Oliveira GS, Valério JB, Daroda, Daroda RF, LSL Brandão $\mathrm{G}$, et al.. Ameloblastic fibro-odontosarcoma: a case report. Int J Oral Maxillofac Surg 2009;38:289-292. Doi: 10.1016/j.ijom.2008.11.025.

77. Kousar A, Hosein MM, Ahmed Z, Minhas K. Rapid sarcomatous transformation of an ameloblastic fibroma of the mandible: case report and literature review. Oral Surg Oral Med Oral Pathol Oral Radiol Endod 2009;108:e80-5. Doi: 10.1016/j.tripleo.2008.07.031.

78. Guthikonda B, Hanna EY, Skoracki RJ, Prabhu SS. Ameloblastic fibrosarcoma involving the anterior and middle skull base with intradural extension. J Craniofac Surg 2009;20:2087-2090.

79. Pontes HAA, Pontes FSS, Silva BS, Cury SEV, Fonseca FP, Salim, RA, et al.. Immunoexpression of Ki67, proliferative cell nuclear antigen, and $\mathrm{Bcl}-2$ proteins in a case of ameloblastic fibrosarcoma. Ann Diagn Pathol 2010;14:447-452.

80. Gupta N, Barwad A, Kumar R, Rijuneeta, Vaiphei K. Ameloblastic fibrosarcoma: a cytologist's perspective. Diagn Cytopathol 2011;39:598602. Doi: $10.1002 /$ dc. 21500

81. Wang $\mathrm{S}$, Shi H, Wang P, Yu Q. Ameloblastic fibro-odontosarcoma of the mandible: imaging findings. Dentomaxillofac Radiol 2011;40:324-327.

82. Demoor-Goldschmidt C, Minard-Colin V, Cassagneau E, Supiot S, Oberlin 0, D'hautuille $C$, et al.. Ameloblastic fibrosarcoma of the mandible: report of 2 chemosensitive pediatric cases. J Pediatr Hematol Oncol 2012;34:e72-76.

83. Noordhoek R, Pizer ME, Laskin DM. Ameloblastic fibrosarcoma of the mandible: treatment, long-term follow-up and subsequent reconstruction of a case. J Oral Maxillofac Surg 2012;70:2930-2935.

84. Reiser V, Alterman M, Shuster A, Kaplan I. Pediatric ameloblastic fibro-odontosarcoma of the mandible: a challenge of diagnosis and treatment. J Oral Maxillofac Surg 2013;71:e45-57.

85. Akinyamoju AO, Olusanya AA, Adeyemi BF, Kolude B. Ameloblastic fibrosarcoma: Report of a case. J Oral Maxillofac Pathol 2013;17:424426.

86. Khalili M, Shakib PA. Ameloblastic fibrosarcoma of the upper jaw: Report of a rare case with long-term follow-up. Dent Res J (Isfahan) 2013;10:112-115.

87. Martínez Martínez M, Mosqueda-Taylor A, Carlos R, Delgado-Azañero W, Almeida OP de. Malignant odontogenic tumors: a multicentric Latin American study of 25 cases. Oral Dis 2014;20:380-385.

88. Gilani SM, Raza A, Al-Khafaji BM. Ameloblastic fibrosarcoma: a rare malignant odontogenic tumor. Eur Ann Otorhinolaryngol Head Neck Dis 2014;131:53-56.

89. Hu Y-YY, Deng M-HH, Yuan L-LL, Niu Y-MM. Ameloblastic fibrosarcoma of the mandible: A case report and mini review. Exp Ther Med 2014;8:1463-1466.

90. Giraddi GB, Garg V. Aggressive atypical ameloblastic fibrodentinoma: Report of a case. Contemp Clin Dent 2012;3:97-102.

91. Shetawi H Al, Alpert EH, Buchbinder D, Urken ML. Ameloblastic Fibrosarcoma of the Mandible: A case report and a review of the literature. J Oral Maxillofac Surg 2015;73:1661.e1-7.

92. Lawal A0, Soyele 00, Akinyamoju AO. A retrospective study of 21 cases of malignant odontogenic tumours from two tertiary health centres in Nigeria. Pan Afr Med J 2015;20:371.

93. Mohsenifar Z, Behrad S, Abbas FM. Epithelial dysplasia in ameloblastic fibrosarcoma arising from recurrent ameloblastic fibroma in a 26-yearold Iranian man. Am J Case Rep 2015;16:548-553.

94. Pourdanesh $F_{1}$ Mohamadi M, Moshref M, Soltaninia O. Ameloblastic fibrosarcoma of the mandible with distant metastases. J. Oral Maxillofac Surg 2015;73:2067.e1-e7.

95. Jundt $G$, Reichart PA. [Malignant odontogenic tumors]. Pathologie 2008:29:205-213.
96. Kumar N Jain S. Aspiration cytology of ameloblastic fibroma: a diagnostic challenge. Diagn Cytopathol 2003;29:101-104.

97. Bocklage TJ, Ardeman T, Schaffner D. Ameloblastic fibroma: a fineneedle aspiration case report. Diagn Cytopathol 1997;17:280-286.

98. Dahlin DC, Ivins JC. Fibrosarcoma of bone. A study of 114 cases. Cancer 1969;23:35-41.

99. Lolachi CM, Madan SK. Ameloblastic carcinoma of the maxilla J Laryngol Otol. 1995;109:1019-1022.

100. Manor E, Kan E, Bodner L. Ameloblastic fibroodontoma of the mandible with normal karyotype in a pediatric patient. Case Rep Dent 2012;2012:969687

101. Kunkel M, Ghalibafian M, Radner H, Reichert TE, Fischer B, Wagner W. Ameloblastic fibrosarcoma or odontogenic carcinosarcoma: a matter of classification? Oral Oncol 2004;40:444-449.

102. Reichart PA, Jundt G. [Benign "mixed" odontogenic tumors]. Pathologie. 2008;29:189-198.

103. Kulkarni RS, Sarkar A, Goyal S. Recurrent ameloblastic fibroma: report of a rare case. Case reports in dentistry. 2013;2013-2014.

104. Slater U. Odontogenic sarcoma and carcinosarcoma. Semin Diagn Pathol 1999;16:325-332.

105. Takeda Y. Ameloblastic fibroma and related lesions: current pathologic concept. Oral Oncol 1999;35:535-540.

106. Wang L, Lu Y, Takashi, T Zhao M, Wu L, Zhou Z, et al.. [Ameloblastic fibrosarcoma: an immunohistochemical and ultrastructural study of the mesenchymal component]. Hua Xi Yi Ke Da Xue Xue Bao 1999;30:318-320, 323

107. Nagatsuka H, Siar CH, Nakano K, Tsujigiwa H, Gunduz M, Choufuku H, et al.. Differential expression of collagen IV alpha1 to alpha6 chains in basement membranes of benign and malignant odontogenic tumors. Virchows Arch 2002;441:392-399.

108. Takagi M, Ishikawa G. A case of ameloblastic sarcoma. Nikon byorigakkai kaishi. Tr Soc Path Jap 1972;61:144. (in Japanese).

109. Shimozato T, Hamada G, Tanaka Y, Iwabori M, Yamamoto M. A case of ameloblastoma accompanied with sarcoma. Nikon kokugekagakkai zasshi. Japan J Oral Surg 1959;5:47-49 (in Japanese);

110. Eda S, Ichikawa T, Koike H, Tachikawa T, Yamane H, Shimono M, et al. A case report of ameloblastic fibrosarcoma. Nihon byorigakkai kaishi. Tr Soc Path Jap 1973;62:230-231. (in Japanese).

111. Herzog U, Putzke HP, Bienengräber V, Radke C. [The ameloblastic fibro-odontoma--an odontogenic mixed tumor progressing into an odontogenic sarcoma]. Dtsch Z Mund Kiefer Gesichtschir 1991;15:9093.

112. Gupta DS, Gupta MK, Wadkar MA, Soni PH. Ameloblastic fibroma or ameloblastic fibrosarcoma. A case report. J Indian Dent Assoc 1982;54:445-447.

113. Sano $K$, Yoshida $S$, Ninomiya $H$, Ikeda $H$, Ueno $K$, Sekine J, et al.. Assessment of growth potential by MIB-1 immunohistochemistry in ameloblastic fibroma and related lesions of the jaws compared with ameloblastic fibrosarcoma. J Oral Pathol Med 1998;27:59-63.

114. Buchner A, Merrell PW, Carpenter WM. Relative frequency of central odontogenic tumors: a study of 1,088 cases from Northern California and comparison to studies from other parts of the world. J Oral Maxillofac Surg 2006;64:1343-1352.

115. Jing $W, X$ uan $M$, Lin $Y, W u L$, Liu L, Zheng $X$, et al.. Odontogenic tumours: a retrospective study of 1642 cases in a Chinese population. Int J Ora Maxillofac Surg 2007;36:20-25.

116. Luo H-YY, Li T-JJ. Odontogenic tumors: a study of 1309 cases in a Chinese population. Oral Oncol 2009;45:706-711.

117. Osterne RL, Brito RG, Alves AP, Cavalcante RB, Sousa FB. Odontogenic tumors: a 5-year retrospective study in a Brazilian population and analysis of 3406 cases reported in the literature. Oral Surg Oral Med Oral Pathol Oral Radiol Endod 2011;111:474-481.

118. Fernandes A, Duarte E, Pimenta F, Souza LN, Santos VR, Mesquita RA, Aguiar MCF. Odontogenic tumors: a study of 340 cases in a Brazilian population. J Oral Pathol Med 2005;34:583-587.

119. Santos TS, Andrade E, Dourado E. Odontogenic tumors: clinical and pathology study of 238 cases. Rev Bras Otorrinol 2008;74:668-673.

120. Costa DOPO, Maurício ASS, de Faria PASA, Silva LEE, Mosqueda-Taylor A, Lourenço SOCD. Odontogenic tumors: a retrospective study of four 
Brazilian diagnostic pathology centers. Med Oral Patol Oral Cir Bucal 2012;17:e389-394.

121. DeLair D, Bejarano PA, Peleg M, El-Mofty SK. Ameloblastic carcinosarcoma of the mandible arising in ameloblastic fibroma: a case report and review of the literature. Oral Surg Oral Med Oral Pathol Oral Radiol Endod 2007;103:516-520.

122. Chikosi R, Segall N, Augusto P, Freedman P. Odontogenic carcinosarcoma: case report and literature review. J Oral Maxillofac Surg 2011;69:1501-1507.

123. Galvão $\mathrm{CF}$, Gomes $\mathrm{CC}$, Diniz MG, Vargas $\mathrm{PA}$, de Paula $\mathrm{AM}$, MosquedaTaylor A, et al.. Loss of heterozygosity $(\mathrm{LOH})$ in tumour suppressor genes in benign and malignant mixed odontogenic tumours. J Oral Pathol Med 2012;41:389-393.

124. Slama A, Yacoubi T, Khochtali H, Bakir A. [Mandibular odontogenic carcinosarcoma: a case report]. Rev Stomatol Chir Maxillofac 2002;103:124-127.
Received August 23, 2016

Accepted January 3, 2017 